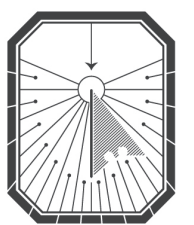

KYIV-MOHYLA

LAW \& POLITICS JOURNAL

KYIV-MOHYLA SCHOLARLY PEER-REVIEWED JOURNALS

Post-Conflict Reparation: Ukrainian Restitution Remedies for Property and Restitution Complaints before the European Court of Human Rights

Author(s): Tetyana Antsupova

Source: Kyiv-Mohyla Law and Politics Journal 2 (2016): 217-226

Published by: National University of Kyiv-Mohyla Academy

http://kmlpj.ukma.edu.ua/ 


\title{
Post-Conflict Reparation: Ukrainian Restitution Remedies for Property and Restitution Complaints before the European Court of Human Rights
}

\section{Tetyana Antsupova}

International Humanitarian University,

International Law and Comparative Law Department

\begin{abstract}
This article describes the proposed Ukrainian legislation on national remedies for the restitution of property damaged or destroyed during the conflicts in Eastern Ukraine and Crimea. Noting gaps in this proposed legislation, it emphasizes the need for an effective National Strategy for post-conflict reparations and a related Action Plan. The article also analyzes the European Court of Human Rights' decision in Lisnyy and Others v. Ukraine and Russia, in which the Court ruled inadmissible for want of evidence the applicants' complaints about the shelling of their homes in Eastern Ukraine during the hostilities there that began in April 2014. The article concludes by examining the Lisnyy and Others v. Ukraine and Russia decision's implications for a national remedy for the restitution of property damaged or destroyed during the ongoing hostilities.
\end{abstract}

Key Words: Restitution (restitutio in integrum), the case of Lisnyy and Others v. Ukraine and Russia, internally displaced persons, compensation for housing destroyed or damaged, Article 1 of Protocol No. 1 to the ECHR, European Court of Human Rights.

\section{Introduction}

In spring 2014, Ukraine joined the ranks of the conflict zones in Europe. Since then, three interState applications and approximately three thousand individual applications ${ }^{1}$ related to the events in Crimea or the hostilities in Eastern Ukraine were brought or are pending before the European Court of Human Rights. They include a wave of complaints about property losses against the Russian Federation and Ukraine.

This wave of complaints is partly because Ukraine lacks an effective national remedy for property losses under its National Strategy for post-conflict reparation and its related Action Plan. Lacking an effective national remedy, owners of damaged or destroyed property have turned for relief to international judicial and quasi-judicial bodies, primarily the European Court of Human Rights.

1 “Ukraine. Press Country Profile," accessed August 26, 2016, http://www.echr.coe.int/Documents/ CP_Ukraine_ENG.pdf 
This article discusses the draft Ukrainian legislation on national remedies for the restitution of property and analyzes the European Court of Human Rights' decision in Lisnyy and Others v. Ukraine and Russia. It then recommends the best way for property owners to protect their property rights.

\section{Ukrainian Legislation on National Remedies for the Restitution of Property}

Ukraine's adoption of a National Human Rights Strategy in 2015 raised hopes that Ukraine would give appropriate attention to the plight of its displaced persons. ${ }^{2}$ The Strategy's Chapter on the "Protection of the Rights of Internally Displaced Persons" mentions the following expected outcomes:

- conditions are created for voluntary return of internally displaced persons to their former permanent places of residence;

- efficient mechanisms for promoting the observance and restoration of rights and freedoms of internally displaced persons are introduced;

- international legal mechanisms for the protection of rights and freedoms of internally displaced persons are used.

To achieve these outcomes, Ukraine adopted an Action Plan on the implementation of the National Human Rights Strategy until 2020. This Plan includes 135 provisions that describe the government's measures for implementing the Strategy, including the following:

10) formation of a working group to develop the procedure of compensation for property that was damaged as a result of anti-terrorist operation;

12) development of a draft legal act based on the analysis conducted by a working group regarding the procedure of compensation for the value of the damaged property with obligatory reference to mechanism of compensation charges, sources of payment of the compensation, mechanism of donors and investors' involvement. ${ }^{3}$

The Order No. 69 of the Ministry of Regional Development of Ukraine of 25 March 2016 created the working group described in the Action Plan. ${ }^{4}$ Yet Ukraine's Parliament is still

"National Human Rights Strategy (Approved by the Decree of the President of Ukraine of 25 August 2015, No. 501/2015)," trans. UN OHCHR in Ukraine, accessed August 26, 2016. www.legislationline. org/.../Ukraine_NHRStrategy_2015_en.

3 "Annex to the Order No. 1393-r of the Cabinet of Ministers of Ukraine of November 23, 2015. The Action Plan on the Implementation of the National Strategy on Human Rights for the Period until 2020," accessed August 26, 2016, http://www.kmu.gov.ua/control/uk/cardnpd?docid=248740679. "Report on Execution of Action Plan on the Implementation of the National Strategy on Human Rights for the Period 2020," Ministry of Justice of Ukraine, accessed August 26, 2016, old.minjust.gov. ua/file//52389. 
considering the procedure for compensating owners of damaged or destroyed property. Four different draft laws have been proposed.

On 11 November 2015, Ukraine's Parliament registered the first of these draft laws - draft law No. $3434^{5}$ "On amendments to the Law of Ukraine 'On Combating Terrorism' Concerning Compensation for Housing Damaged as a Result of the 'Anti-Terrorist Operation." This draft law provides for compensation for damages only for damaged or destroyed housing. It covers damages caused by terrorist acts as well as damages caused by the security operations. However, it does not establish the mechanism for obtaining that compensation. Instead, it stipulates that the mechanism is to be established by the Government of Ukraine.

On 24 March 2016, Parliament registered the second draft law — draft law No. 4301 on compensation for housing destroyed or damaged in the course of "anti-terrorist operation." 6 It also provides for compensation for damages to housing inflicted during the "anti-terrorist operation" in the Donetsk and Luhansk regions. If enacted, this compensation program will be conducted in 2016-2017 by the Ministry of Regional Development. The draft law distinguishes among three levels of damages in determining the amount of compensation:

1) complete destruction;

2) damages requiring capital reconstruction; and

3) damages requiring routine repairs.

The draft law expressly provides that compensation will be possible only for the property located in the territory controlled by Ukraine (excluding the localities along the contact line and the "grey zone" until the renewal of control over those territories). Applicants (an owner or his/her representative) must apply for compensation to the local self-government authorities. Commissions established within the local self-government bodies will assess the damages and decide on compensation. The draft law establishes the procedure for assessing damages. Under Article 2(3) of the draft law, the Commission will assess the damages within a month after the application is registered. The Commission may conduct a re-assessment if the applicant disagrees with the initial assessment. The results of the re-assessment will be final. The draft law also provides that the compensation will be allocated to a special personal bank account, which will allow for the monitoring of the funds to ensure they are used for their targeted purposes.

On 29 March 2016, the Parliament registered the third draft law — draft law No. 4328 on compensation of damages caused by a terrorist act. ${ }^{7}$ Under this draft law, applicants (an owner or his/her representative) will apply for compensation to the regional state administrations. The applications will be reviewed by a special Commission, which will assess the damages

5 Draft law “On Amendments to the Law of Ukraine 'On Combating Terrorism' Concerning Compensation for Housing Damaged in a Result of Anti-Terrorist Operation" of 11 November 2015, No. 3434 .

6 Draft law “On Compensation for Destroyed or Damaged Private Housing to Persons, whose Housing or Household Was Damaged (Destroyed) in the Course of Anti-Terrorist Operation" of 24 March 2016, No. 4301. Authors: Oleh Nedava, Atrur Herasymov, Maksym Yefimov, Dmyrto Lubinets and Maria Ionova (Petro Poroshenko block), and Serhii Sazhko (Opposition block). 
and decide on compensation within 45 days. The Commission's decision can be challenged in an administrative court.

The Commission's compensation award may be paid out at once or in installments over one year. The compensation will be denied if the beneficiary received an insurance indemnity for the damaged or destroyed property.

On 11 April 2016, Parliament registered the fourth draft law - draft law No. 4301-1 on compensation for housing destroyed or damaged in the course of the "anti-terrorist operation." 8 The draft law was introduced as an alternative to draft law No. 4301. Unlike draft law No. 4301, it provides for compensation for expenses incurred by the individuals who reconstructed or repaired the property before the law's entry into force, although this compensation's priority is lower than the three priorities for compensation for damages specified in draft law No. 4301. It also expressly recognizes the State's responsibility for damages caused by the security operation. And unlike the draft law No. 4301, which provides that the compensation program will be conducted in 2016-2017, draft law No. 4301-1 does not set a time frame.

Under any of these draft laws, establishing the actual extent of the damages for properties in the Donetsk and Luhansk regions will be challenging. A special Commission tasked with assessing the damages and deciding on compensation will not have access to the property located in the territories that are beyond Ukraine's control. Nevertheless, Ukraine still has positive obligations in these territories under Article 1 Protocol 1 to the European Court of Human Rights. Under the notification of derogation dated 5 June 2015,

Ukraine exercises the right of derogation from its obligations established in [...] Articles 5, 6, 8 and 13 of the Convention for the Protection of Human Rights and Fundamental Freedoms, in certain areas of the Donetsk and Luhansk oblasts of Ukraine, which is determined by the Anti-Terrorist Centre of the Security Service of Ukraine in connection with the antiterrorist operation... ${ }^{9}$

Thus, Ukraine still has positive obligations under Article 1 Protocol 1 of the Convention, to which the derogation did not apply. For national remedies to be effective, the local Commissions must be able to assess the damages in the territories beyond the Ukrainian authorities' control.

According to the Declaration contained in a Note verbale from the Permanent Representation of Ukraine dated 29 June 2016,

the Permanent Representation of Ukraine to the Council of Europe emphasizes once again the need to adopt a very careful approach for the establishment of facts as to whether the areas of Donetsk and Luhansk

8 Draft law "On Compensation of Damages Inflicted to Housing in the Course of Anti-Terrorist Operation" of 11 April 2016, No. 4301-1.

9 "Reservations and Declarations for Treaty No. 005 - Convention for the Protection of Human Rights and Fundamental Freedoms," accessed August 26, 2016, http://www.coe.int/en/web/conventions/ full-list/-/conventions/treaty/oo5/declarations?p_auth=r5TEKPVj. 
oblasts of Ukraine, which as specified in this Note Verbale, are partially controlled by the Government of Ukraine, are under effective overall control and jurisdiction of either Ukraine or Russian Federation as an Aggressor State. The European Court of Human Rights will have to take into account the particular circumstances of each case at a given moment in time..$^{10}$

\section{The European Court of Human Rights' Reparations Jurisprudence}

The European Court of Human Rights has a rich reparations jurisprudence involving armed conflicts in Europe. As Judge Hanna Yudkivska has noted, "the Court applied the principle of restitutio in integrum for the first time in the landmark case of Papamichalopoulos and Others $v$. Greece, concerning unlawful expropriation:

...the Court considers that the return of the land in issue $[\ldots]$ would put the applicants as far as possible in a situation equivalent to the one in which they would have been if there had not been a breach of Article 1 of Protocol No. 1.

In so doing it was inspired by the judgment of the Permanent Court of International Justice (PCIJ) in the Chorzów Factory case, where the PCIJ held that "reparation must, as far as possible, wipe out all the consequences of the illegal act and re-establish the situation which would in all probability have existed if that act had not been committed."11

It is hard to disagree with professor Antoine Buyse's conclusion that

only in the 1990s, $[\ldots]$ the Court started to indicate in some cases which specific form of reparation would be the most appropriate. Although it kept emphasizing that states could choose the means of implementation of judgments, it has developed the general principle that states should provide restitutio in integrum whenever possible - a clear reflection of general international law. ${ }^{12}$

Later, the European Court of Human Rights faced violations of Article 1 Protocol No. 1 to the Convention in these and many other post-conflict cases: Loizidou v. Turkey (1998), Cyprus v. Turkey (2001), Broniowskiv. Poland (2004), Xenides-Arestis v. Turkey (2005), Radanovic v. Croatia (2006), Kunic v. Croatia (2007), Khamidov v. Russia (2007), Demopoulos and others

10 "Reservations and Declarations for Treaty No. 005."

11 Oleksandr Volkovv. Ukraine (Application No. 21722/11), January 9, 2013. Concurring Opinion of Judge Yudkivska.

12 Antoine Buyse, "Lost and Regained? Restitution as a Remedy for Human Rights Violations in the Context of International Law," Heidelberg Journal of International Law (Zeitschrift für ausländisches öffentliches Recht und Völkerrecht) 68 (2008): 153. 
v. Turkey (2010), Đokić v. Bosnia and Herzegovina (2010), Kerimova and Others v. Russia (2011), Miltayev and Meltayeva v. Russia (2013), Chiragov and Others v. Armenia (2015), Sargsyan v. Azerbaidjan (2015), and Salamov v. Russia (2016).

Referring, for instance, to the case of Chiragov and Others v. Armenia we may find the proof of the importance of effective domestic remedies in the context of post-conflict reparation:

Guidance as to which measures the respondent Government could and should take in order to protect the applicant's property rights can be derived from relevant international standards, in particular from the UN Pinheiro Principles [...] and the above-mentioned Resolution of the Parliamentary Assembly of the Council of Europe (Resolution 1708 (2010) "On Solving Property Issues of Refugees and Displaced Persons." Tetyana Antsupova). At the present stage, and pending a comprehensive peace agreement, it would appear particularly important to establish a property claims mechanism, which should be easily accessible and provide procedures operating with flexible evidentiary standards, allowing the applicants and others in their situation to have their property rights restored and to obtain compensation for the loss of their enjoyment. ${ }^{13}$

\section{The Case of Lisnyy and Others v. Ukraine and Russia}

Since the conflict in Ukraine began and the first applications were lodged with the Court, Ukraine's legal community has been waiting for the decisions and/or judgments in cases related to the events in Crimea or the hostilities in Eastern Ukraine. On 28 July 2016, the wait ended. In the case of Lisnyy and Others v. Ukraine and Russia the Court for the first time declared inadmissible three applications concerning three Ukrainian nationals' complaints about the shelling of their respective homes during the hostilities in Eastern Ukraine from the beginning of April 2014.14 Thus, this decision might instruct potential applicants in similar circumstances and their representatives.

The applicants complained that their lives had been put at risk by the shelling of the villages where they lived and that their property had either been destroyed or damaged. They also complained more generally that all the State institutions in Eastern Ukraine, including the courts, had suspended their operations and had been relocated to areas controlled by Ukraine. They relied on Article 1 of Protocol No. 1 (protection of property) of the European Convention on Human Rights and on other grounds.

In its reasoning, the Court began by reiterating a crucial principle:

The proceedings before the Court are adversarial in nature. It is therefore for the parties to substantiate their factual arguments by providing the Court with the necessary evidence. Whereas the Court is responsible for 
establishing the facts, it is up to the parties to provide active assistance by supplying it with all the relevant information. ${ }^{15}$

The Court referred to the case of Ireland $v$. the United Kingdom and its statement that

the Court adopts the standard of proof "beyond reasonable doubt" but adds that such proof may follow from the coexistence of sufficiently strong, clear and concordant inferences or of similar unrebutted presumptions of fact. In this context, the conduct of the Parties when evidence is being obtained has to be taken into account. ${ }^{16}$

The Court knows that certain exceptional circumstances beyond the applicants' control can cause applicants difficulties in submitting documentary evidence to support their complaints. It therefore has been its consistent practice to apply a more lenient approach where a cogent argument is made by reference to such circumstances. ${ }^{17}$

The most illustrative cases in this regard are the so-called Chechen cases. There, the Court has essentially reviewed two types of complaints brought by residents of Chechnya concerning violations of their property rights during anti-terrorist operations. ${ }^{18}$ Aspects of the relevant national legal practice have been summarized in the judgments Esmukhambetov and Others v. Russia ${ }^{19}$ and Kerimova and Others v. Russia. ${ }^{20}$ In Kerimova and Others v. Russia, the Court accepted the ownership claims of applicants who relied on extracts from a housing inventory (certificates) issued by the town administration after the attack that caused the damage. The Court observed,

it is true that these latter certificates provided no information as to whether the applicants mentioned in them had title to those properties; however, they gave a clear indication that the properties had been damaged during the military actions. It is therefore not unlikely that any documents confirming those applicants' title to the houses were destroyed together with their possessions during the attack. ${ }^{21}$

Nevertheless, the Court noted that the applicants in Lisnyy and Others v. Ukraine and Russia

Lisnyy and Others v. Ukraine and Russia (Dec.), Nos. 5355/15, 44913/15 and 50853/15, July 28, 2016, para 25 .

16 Ireland v. the United Kingdom, No. 5310/71, January 18, 1978.

17 Lisnyy and Others v. Ukraine and Russia (Dec.), Nos. 5355/15, 44913/15 and 50853/15, July 28, 2016, para 29.

18 Miltayev and Meltayeva v. Russia, No. 8455/o6, January 15, 2013, para 54.

19 Esmukhambetov and Others v. Russia, No. 23445/o3, March 29, 2011.

20 Kerimova and Others v. Russia, Nos. 17170/o4, 20792/o4, 22448/o4, 2336o/o4, 5681/o5 and 5684/05, May 3, 2011. 
have not made any submissions as to the reasons for which they have failed to submit any relevant documents supporting their Convention claims... Nor have they informed the Court of any attempts they may have made in order to obtain at least fragmentary documentary evidence to substantiate their allegations. ${ }^{22}$

Although the applicants in this case were represented, they had submitted only copies of their passports. Mr. Lisnyy had submitted photographs of a destroyed house but not proof of his ownership of that house or any other right that he might have had in it. Nor had the applicants explained why they had failed to support their Convention claims with any relevant documents, such as land or property titles, extracts from land or tax registers, documents from the local administration, plans, photographs and maintenance receipts as well as proof of mail deliveries or witness statements. Moreover, they did not inform the Court of any attempts they might have made to obtain at least fragmentary documentary evidence to substantiate their allegations. ${ }^{23}$

The Court repeated its earlier, oft-repeated admonition: "If an applicant does not produce any evidence of title to property or of residence, his complaints are bound to fail." ${ }^{24}$ The Court has consistently held to this rule. ${ }^{25}$

In sum, the main reason for the inadmissibility of the case Lisnyy and Others $v$. Ukraine and Russia was the absence of prima facie evidence of property ownership. The applications being ill-founded, were rejected in accordance with Article 35 paras 3 (a) and 4 of the Convention.

\section{Further Developments}

Under the Court's well-established jurisprudence in cases seeking post-conflict reparations, potential applicants seeking restitution for their damaged or destroyed property against the Russian Federation and Ukraine might face problems satisfying at least two more requirements: 1) the exhaustion of domestic remedies, and 2) proof that a State interfered with their rights under Article 1 of Protocol No. 1.

However, as to the latter potential problem, the PACE's position in its Resolution 2133 $(2016)^{26}$ greatly clarified the official view of the Council of Europe and might cause the European Court of Human Rights to follow the same reasoning as PACE did:

Lisnyy and Others v. Ukraine and Russia (Dec.), Nos. 5355/15, 44913/15 and 50853/15, July 28, 2016, para 3 .

Press Release, ECHR 263 (2016), July 28, 2016. Complaints concerning shelling of homes in Eastern Ukraine declared inadmissible due to lack of evidence.

Lisnyy and Others v. Ukraine and Russia (Dec.), Nos. 5355/15, 44913/15 and 50853/15, July 28, 2016, para 26.

25 See, for instance, Sargsyan v. Azerbaijan [GC], No.40167/06, para 183, June 16, 2015; Lordos and Others v. Turkey, No. 15973/9o, para 50, November 2, 2010; Damayev v. Russia, No. 36150/04, paras 108-11, May 29, 2012; Prokopovich v. Russia, No. 58255/oo, para 37, ECHR2004-XI; and Elsanova v. Russia (Dec.), No. 57952/oo, November 15, 2005.

PACE. Resolution 2133 (2016) "Legal Remedies for Human Rights Violations on the Ukrainian Territories Outside the Control of the Ukrainian Authorities," text adopted by the Assembly on 12 
The "DPR" and "LPR" - established, supported and effectively controlled by the Russian Federation - are not legitimate under Ukrainian or international law. This applies to all their "institutions," including the "courts" established by the de facto authorities. Under international law, the Russian Federation, which exercises de facto control over these territories, is responsible for the protection of their populations. Russia must therefore guarantee the human rights of all inhabitants of Crimea and of the "DPR" and "LPR." 27

But this does not relieve Ukraine's obligation to establish a property claims mechanism that allows applicants and others in their situation to have their property rights restored. Thus, unless Ukraine satisfies this obligation, applicants will not have an effective remedy to exhaust before the seek relief from the European Court of Human Rights.

\section{Concluding Remarks}

The lesson of Lisnyy and Others v. Ukraine and Russia is that restitution complaints before the European Court of Human Rights must be supported by sufficient evidence. Otherwise, applicants must explain why they failed to submit sufficient evidence or inform the Court of any attempts they might have made to obtain at least fragmentary documentary evidence to substantiate their allegations. The Court has clearly demonstrated that unjustified complaints will be dismissed and that complaints must be sufficiently substantiated under Rule $44 \mathrm{C}$ para 1 of the Rules of Court. ${ }^{28}$

Perhaps Ukraine's creation of a national mechanism for assessing damages for destroyed property will play two important roles: 1) serving as a national, effective legal remedy for the protection of property rights in Ukraine; and 2) if the applicant disagrees with the national final decision, providing important evidence (at least an assessment of damages) for further proceedings before the European Court of Human Rights.

Under the principle of subsidiarity, the primary obligation for remedying violations of an applicant's right under Article 1 of Protocol No. 1 resides at the national level.

\section{Bibliography}

Allen, Tom. "Restitution and Transitional Justice in the European Court of Human Rights." Columbia Journal of European Law 13.1 (2007): 1-46.

October 2016 (33rd sitting), accessed October 14, 2016, http://assembly.coe.int/nw/xml/XRef/Xref-

XML2HTML-en.asp?fileid=23167\&lang=en.

27 PACE. Resolution 2133 (2016) “Legal Remedies for Human Rights Violations," paras 3, 4.

28 Rule $44 \mathrm{C} 1$ - Failure to participate effectively 1 . Where a party fails to adduce evidence or provide information requested by the Court or to divulge relevant information of its own motion or otherwise fails to participate effectively in the proceedings, the Court may draw such inferences as it deems appropriate. 
Antsupova, Tetyana. "European Convention on Human Rights as a Legal Basis of the Concept of Positive Obligations of the States-Parties." In The Influence of Contemporary Constitutions on Relations between Individuals, edited by M. Florczak-Wator, 259-78. Kraków: Księgarnia Akademicka, 2015 .

Ballard, Megan J. "Post-Conflict Property Restitution: Flawed Legal and Theoretical Foundations." Berkeley Journal of International Law 28.2 (2010): 462-96.

Buyse, Antoine. "Lost and Regained? Restitution as a Remedy for Human Rights Violations in the Context of International Law." Heidelberg Journal of International Law (Zeitschrift für ausländisches öffentliches Recht und Völkerrecht) 68 (2008): 129-53.

Drucker, Alfred. "Restitution in International Law." The International and Comparative Law Quarterly 15.1 (1966): 263-69.

\section{(2)}

Tatyana Antsupova is Dr. habil. (International Law) and Professor of International Law and Comparative Law Department at International Humanitarian University (Odesa, Ukraine). She is an author of the monograph Council of Europe Procedural Law: Issues of Theory and Practice (2013) and more than 80 other papers, book chapters and monographs in the field of International Procedural Law, Law of International Organizations, European Human Rights Law, and practice of the European Court of Human Rights. Since 2004 she has been teaching the Council of Europe Law and the Case Law of the European Court of Human Rights at National University "Odesa Law Academy" and International Humanitarian University. 